\title{
ANALISIS KARAKTERISTIK MASSA BATUAN DI SEKTOR LEMAJUNG, KALAN, KALIMANTAN BARAT
}

\author{
ANALYSIS OF ROCK MASS CHARACTERISTICS \\ IN LEMAJUNG SECTOR, KALAN, WEST KALIMANTAN
}

\author{
Heri Syaeful" dan Dhatu Kamajati \\ Pusat Teknologi Bahan Galian Nuklir - BATAN \\ Jl. Lebak Bulus Raya No. 9 Pasar Jumat, Jakarta 12440 \\ *E-mail: syaeful@batan.go.id
}

Naskah diterima: 5 November 2014, direvisi: 27 Februari 2015, disetujui: 11 Mei 2015

\begin{abstract}
ABSTRAK
Karakterisasi massa batuan diperlukan dalam suatu rancangan bukaan batuan, dimana perhitungan sifat-sifat teknis dari massa batuan menjadi hal yang penting untuk diperhatikan. Sektor Lemajung merupakan salah satu area prospek untuk penambangan uranium di Kalan, Kalimantan Barat. Tujuan penelitian adalah mendapatkan data karakteristik massa batuan yang merupakan data dasar bagi perencanaan pengembangan teknik penambangan cebakan bahan galian. Metodologi yang digunakan adalah dengan pengambilan contoh batuan untuk analisis laboratorium mekanika batuan, pengamatan rekahan, dan pengamatan kondisi airtanah. Parameter batuan yang dianalisis meliputi uniaxial compressive strength (UCS), rock quality designation (RQD), jarak rekahan, kondisi rekahan, dan airtanah. Hasil analisis menyimpulkan bahwa metalanau sebagai litologi yang mengandung uranium di Sektor Lemajung mempunyai nilai rock mass rating (RMR) sebesar 56 atau kelas massa batuan III: fair rock pada kedalaman sekitar 60 m, dan pada kedalaman 280 m nilai RMR mencapai 82 atau kelas massa batuan I: very good rock. Data nilai RMR tersebut selanjutnya dapat digunakan dalam analisis pembuatan terowongan pada model tambang bawah tanah atau analisis kestabilan lereng pada model tambang terbuka.
\end{abstract}

Kata kunci: karakteristik massa batuan, rock quality designation, rock mass rating, Lemajung, Kalan

\section{ABSTRACT}

Rock mass characterization is required in design of rock opening, which calculation of engineering characters of rock mass become one important parameter to consider. Lemajung sector is one of prospect area for uranium mining in Kalan, West Kalimantan. Purpose of research is to acquire rock mass characteristics as basic data for planning the development of mining technique of ore deposit. Methodology applied is rock sampling for rock mechanic laboratory analysis, observation of joints, and observation of groundwater condition. Rock parameters analyzed includes uniaxial compressive strength (UCS), rock quality designation $(R Q D)$, joint spacing, joint condition, and groundwater. Analysis concluded that metasiltstone 
which is lithology contained uranium in Lemajung Sector has rock mass rating (RMR) value of 56 or rock mass class III: fair rock in the depth of around $60 \mathrm{~m}$, and in the depth of $280 \mathrm{~m}$ $R M R$ value reach 82 or rock mass class I: very good rock. RMR value data furthermore could be used for analysis of tunneling in the model of underground mine or slope stability analysis in the model of open pit mine.

Keywords: rock mass characteristic, rock quality designation, rock mass rating, Lemajung, Kalan

\section{PENDAHULUAN}

Pekerjaan pemboran eksplorasi/evaluasi, pemetaan geologi, dan pemetaan radiometri dilaksanakan pada tahun 2013 di Sektor Lemajung, Kalan sebagai bagian dari kegiatan reevaluasi dan peningkatan kategori sumberdaya uranium dari tingkat terindikasi menjadi terukur. Tahapan kegiatan reevaluasi sumberdaya terdiri dari pembuatan basis data, interpretasi geologi dan pemodelan, dan estimasi sumberdaya mineral ${ }^{[1]}$. Sebagai lanjutan dari kegiatan eksplorasi, dilakukan kegiatan karakterisasi massa batuan yang bertujuan mengetahui karakteristik batuan yang merupakan data dasar bagi kegiatan pengembangan teknik penambangan cebakan bahan galian.

Pada kegiatan perencanaan, desain, dan perawatan struktur bangunan seperti bendungan, terowongan, pembangkit listrik bawah tanah, jalan tol, dan lainnya, diperlukan pertimbangan dimensi dan geometri bangunan, sifat teknik dari bangunan dan material geologi, dan alternatif desain termasuk performanya berdasarkan aspek stabilitas, deformasi, ekonomi, dan keamanan ${ }^{[2]}$. Karakterisasi massa batuan diperlukan dalam suatu rancangan terowongan pada tambang bawah tanah, dimana perhitungan sifat-sifat teknis dari massa batuan menjadi hal yang penting untuk diperhatikan. Untuk mencapai hal tersebut, deskripsi secara kualitatif dinilai tidak mencukupi untuk dipergunakan dalam perhitungan rancangan sehingga kemudian harus dikembangkan secara kuantitatif dalam bentuk nilai (bobot) tertentu, dalam hal ini metode kuantitatif yang akan diterapkan adalah metode rock mass rating (RMR) ${ }^{[3]}$.

Klasifikasi RMR telah diterapkan secara luas dan pada aplikasi yang beragam, seperti terowongan, pondasi, penambangan, dan manajemen geologi bencana. Derajat akurasi dalam prediksi, evaluasi, dan interpretasi kualitas massa batuan merupakan kunci dari pelaksanaan lapangan ${ }^{[4]}$. Rock Mass Rating System atau juga dikenal dengan Geomechanics Classification dikembangkan oleh Bieniawski pada tahun 1972-1973. Metode ini dikembangkan selama bertahuntahun seiring dengan berkembangnya studi kasus yang tersedia dan disesuaikan dengan standar dan prosedur yang berlaku secara internasional ${ }^{[5]}$.

Klasifikasi massa batuan adalah salah satu metode pendekatan yang dapat digunakan untuk desain lubang bukaan bawah tanah. Secara khusus penerapan klasifikasi massa batuan di Lemajung bertujuan untuk mendapatkan data karakteristik massa batuan bagi konsep pengembangan teknik penambangan cebakan bahan galian, yaitu metode penambangan apakah penambangan terbuka atau terowongan. Seperti diketahui pada tahapan estimasi sumberdaya apabila telah memasukkan evaluasi faktor ekonomi 
dan kelayakan tambang maka seluruh faktor terkait metode penambangan harus dikaji secara rinci.

Lokasi penelitian adalah Sektor Lemajung yang merupakan lokasi potensial keberadaan mineralisasi uranium di Cekungan Kalan. Cekungan Kalan secara administratif termasuk ke dalam Desa Kalan, Kecamatan Ella Ilir, Kabupaten Melawi. Daerah ini dapat dicapai dari Kota Pontianak ke Nanga Pinoh yang merupakan ibukota Kabupaten Melawi. Perjalanan Nanga Pinoh menuju Kalan dilalui melewati jalan perusahaan kayu, jalan desa, dan jalan akses khusus menuju Kalan yang keseluruhannya merupakan jalan tanah (Gambar 1).

\section{METODOLOGI}

Terdapat enam klasifikasi massa batuan yang biasa digunakan untuk keperluan desain rekayasa batuan, yaitu rock load classification diusulkan oleh Terzaghi (1946), stand-up time classification yang diusulkan oleh Stini dan Lauffer (1958), rock quality designation (RQD) index yang diusulkan oleh Deere dkk (1988), rock structure rating (RSR) concept diusulkan oleh Wickham dkk. (1972), rock mass rating (RMR) system oleh Bieniawski (1989) dan $Q$-system oleh Barton dkk $(1974)^{[5]}$. Penelitian ini mengaplikasikan rock mass rating (RMR) oleh Bieniawski (1989) yang menggunakan lima parameter utama $^{[6]}$, yaitu:

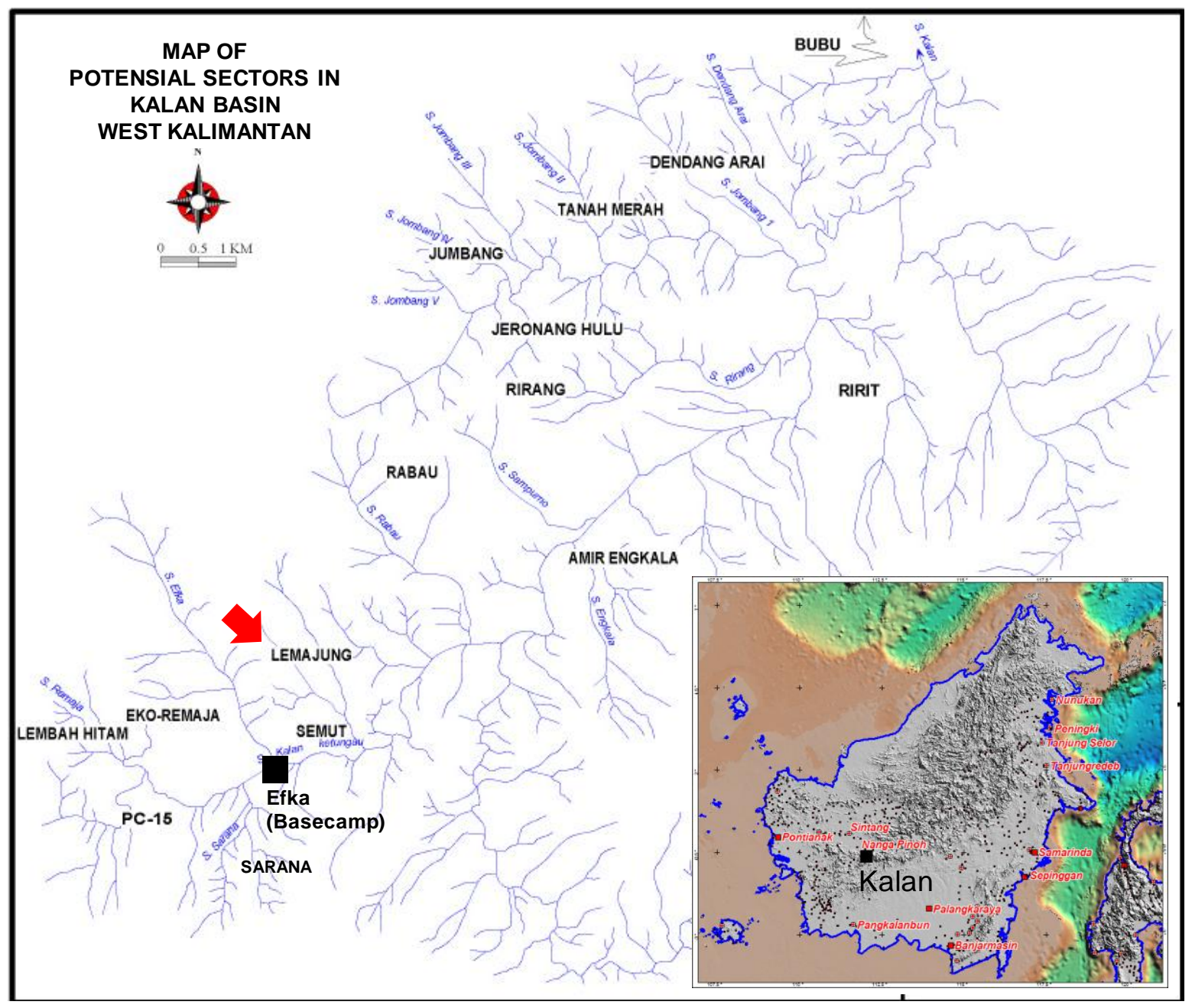

Gambar 1. Peta sektor-sektor potensial di Cekungan Kalan, Kalimantan Barat 
a. Kuat tekan uniaksial (uniaxial compressive strength / UCS)

Merupakan kekuatan dari batuan utuh (intact rock) yang diperoleh dari hasil uji UCS. Uji UCS dilakukan dengan menggunakan peralatan uji tekan contoh batuan dari satu arah (uniaxial). Nilai UCS merupakan besar tekanan yang harus diberikan sampai batuan patah. Berdasarkan data hasil analisis UCS akan didapatkan data kuat tekan uniaksial dan modulus rasio (Tabel $1)^{[7]}$.

Tabel 1. Sifat utama dalam klasifikasi tanah dan batuan $^{[7]}$

\begin{tabular}{|c|c|c|}
\hline Kelas & $\begin{array}{c}\text { Kuat tekan } \\
\text { uniaksial }\end{array}$ & Deskripsi \\
\hline A & $>220 \mathrm{MPa}$ & Sangat kuat \\
\hline B & 110-220 MPa & Kekuatan tinggi \\
\hline $\mathrm{C}$ & 55-110 MPa & Kekuatan menengah \\
\hline $\mathrm{D}$ & 27.5-55 MPa & Kekuatan rendah \\
\hline $\mathrm{E}$ & $<27.5 \mathrm{MPa}$ & Kekuatan sangat rendah \\
\hline Kelas & $\begin{array}{l}\text { Rasio modulus } \\
\qquad(\mathbf{E t} / \sigma c)^{\mathrm{a}}\end{array}$ & Deskripsi \\
\hline $\mathrm{H}$ & $>500$ & Rasio modulus tinggi \\
\hline M & $200-500$ & Rasio modulus menengah \\
\hline $\mathrm{L}$ & $<200$ & Rasio modulus rendah \\
\hline
\end{tabular}

b. Rock quality designation ( $R Q D)$

Merupakan persentase panjang inti bor utuh yang lebih panjang dari $10 \mathrm{~cm}$ terhadap panjang total pengambilan inti/core run (Gambar 2). Diameter inti bor yang digunakan dalam estimasi RQD adalah 54,7 $\mathrm{mm}$ dan menggunakan double/tripple tube core barrel. Perhitungan RQD mengabaikan kekar atau patahnya inti bor yang diakibatkan oleh kegiatan pemboran ${ }^{[8]}$.

\section{c. Spasi rekahan}

Jarak antara spasi rekahan adalah jarak tegak lurus antara bidang-bidang rekahan yang mempunyai kesamaan arah yang berurutan sepanjang garis pengukuran.

\section{d. Kondisi rekahan}

Beberapa parameter digunakan untuk memperkirakan kondisi permukaan rekahan, yaitu:

- Kekasaran (roughness) merupakan permukaan bidang yang kasar sehingga dapat mencegah terjadinya pergeseran antara dua bidang diskontinuitas (Tabel 2).

- Separasi merupakan jarak antara dua permukaan bidang diskontinuitas, umumnya diisi oleh material lainnya atau air. Semakin besar jarak separasi akan semakin lemah bidang diskontinuitas tersebut.

- Kontinuitas merupakan kemenerusan dari sebuah bidang diskontinuitas atau merupakan panjang dari suatu bidang diskontinuitas

- Pelapukan menunjukkan derajat pelapukan permukaan bidang diskontinuitas (Tabel 3).

\section{e. Kondisi air tanah}

Debit aliran air tanah atau tekanan air tanah akan mempengaruhi kekuatan massa batuan. Oleh sebab itu, perlu diperhitungkan dalam klasifikasi massa batuan. Pengamatan terhadap kondisi airtanah dapat dilakukan berdasarkan pengamatan aliran air setiap 10 m kedalaman terowongan, tekanan air tanah, atau menggunakan metode umum melihat permukaan bidang apakah kering, lembab, basah, menetes, atau mengalir. 


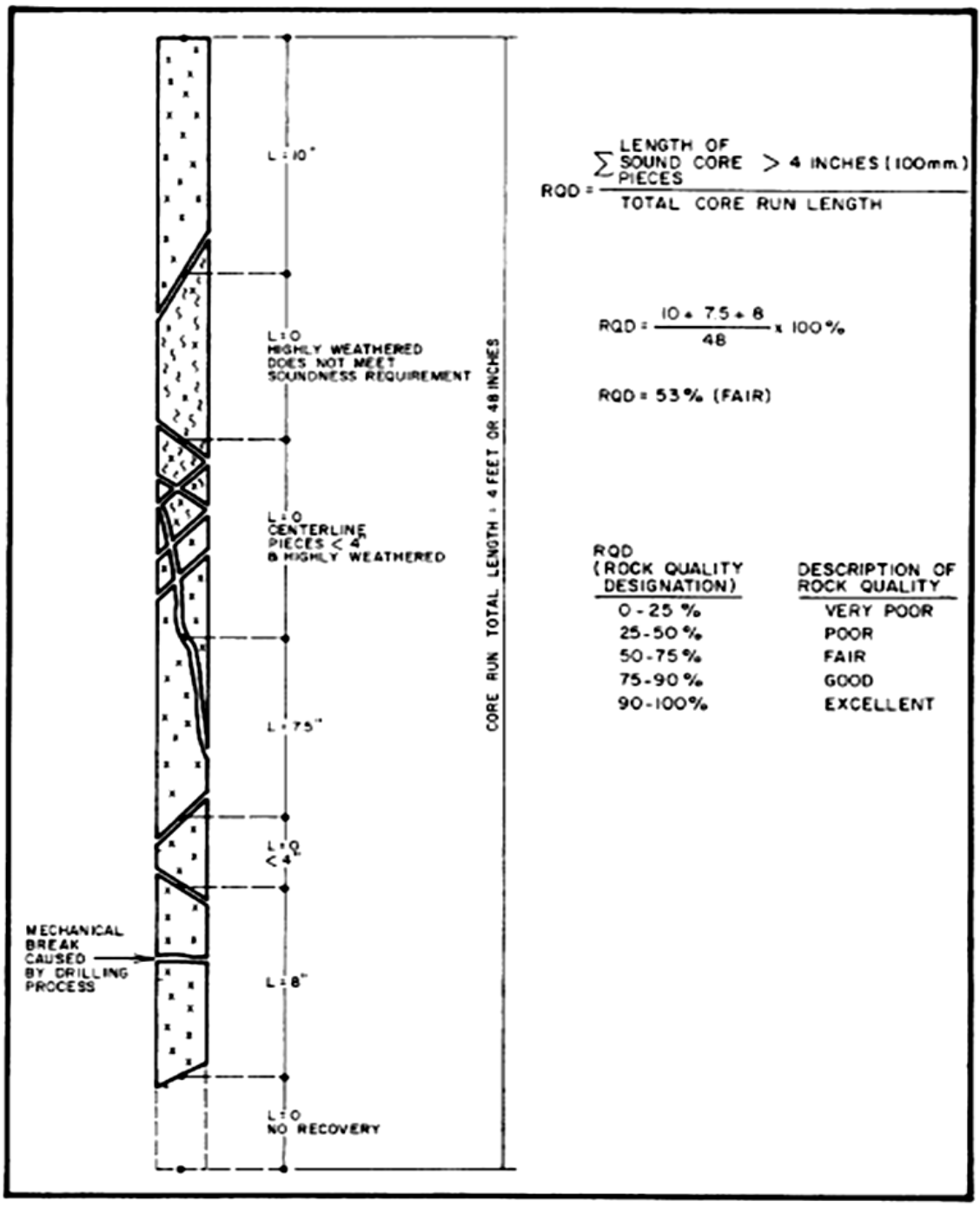

Gambar 2. Prosedur pengukuran dan perhitungan $\mathrm{RQD}^{[8]}$.

Tabel 2. Penggolongan dan pembobotan kekasaran ${ }^{[6]}$

\begin{tabular}{llc}
\hline $\begin{array}{l}\text { Kekasaran } \\
\text { permukaan }\end{array}$ & Deskripsi & Pembobotan \\
\hline Sangat kasar & $\begin{array}{l}\text { Apabila diraba permukaan sangat tidak rata, membentuk } \\
\text { punggungan dengan sudut terhadap bidang datar mendekati } \\
\text { vertikal }\end{array}$ & 6 \\
Kergelombang, permukaan tidak rata, butiran pada permukaan & 5 \\
terlihat jelas, permukaan kekar terasa kasar & $\begin{array}{l}\text { Butiran permukaan terlihat jelas, dapat dibedakan, dan dapat } \\
\text { dirasakan apabila diraba }\end{array}$ & 3 \\
Halus & Permukaan rata dan terasa halus bila diraba & 1 \\
Licin & Permukaan terlihat mengkilap & 0 \\
\hline
\end{tabular}


Tabel 3. Tingkat pelapukan batuan ${ }^{[6]}$.

\begin{tabular}{ll}
\hline Klasifikasi & Keterangan \\
\hline Tidak terlapukkan & Tidak terlihat tanda-tanda pelapukan, batuan segar, butiran kristal terlihat jelas dan terang \\
$\begin{array}{l}\text { Sedikit } \\
\text { terlapukkan }\end{array}$ & $\begin{array}{l}\text { Kekar terlihat berwarna atau kehitaman, biasanya terisi dengan lapisan tipis material } \\
\text { pengisi. Tanda kehitaman biasanya akan nampak mulai dari permukaan sampai kedalam } \\
\text { batuan sejauh 20\% dari spasi }\end{array}$ \\
& $\begin{array}{l}\text { Tanda kehitaman nampak pada permukaan batuan dan sebagian material batuan } \\
\text { terdekomposisi. Tekstur asli batuan masih utuh namun mulai menunjukkan butiran batuan } \\
\text { Terlapukkan }\end{array}$ \\
$\begin{array}{l}\text { Kulai terdekomposisi menjadi tanah. } \\
\text { Keseluruhan batuan mengalami perubahan warna atau kehitaman. Dilihat secara } \\
\text { penampakan menyerupai tanah namun tekstur batuan masih utuh dan butiran batuan telah } \\
\text { terdekomposisi menjadi tanah. }\end{array}$ \\
\hline
\end{tabular}

Data yang dibutuhkan untuk analisis kekuatan batuan diambil dari inti bor pekerjaan pemboran eksplorasi Lemajung tahun 2013. Percontohan inti bor dilakukan dengan sedapat mungkin mewakili level kedalaman batuan, yaitu kedalaman $64 \mathrm{~m}$, $132 \mathrm{~m}$, dan $283 \mathrm{~m}$ dari bor LEML-40, dan kedalaman $198 \mathrm{~m}$ dan $264 \mathrm{~m}$ dari bor LEML39. Preparasi contoh di lapangan dilakukan dengan membungkus batuan dengan plastik wrap dan alumunium foil. Selanjutnya contoh tersebut dimasukkan ke dalam pipa PVC dan dituang cairan parafin agar contoh tidak terdegradasi selama pengiriman ke laboratorium mekanika batuan (Gambar 3).

Analisis laboratorium dilakukan di Laboratorium Mekanika Batuan - Pusat Teknologi Mineral dan Batubara, KESDM. Analisis melingkupi sifat fisik dan sifat teknik dari batuan yang meliputi karakteristik fisik dan mekanik (Tabel 4). Data RQD, jarak rekahan, kondisi rekahan, dan kondisi airtanah didapatkan dari pengamatan lapangan dan deskripsi inti bor (Gambar 4). Hasil perhitungan RMR selanjutnya akan diinterpretasi untuk mengetahui kelas massa batuan, waktu stand-up, kohesi massa batuan, dan sudut friksi massa batuan (Tabel 4) ${ }^{[9]}$.

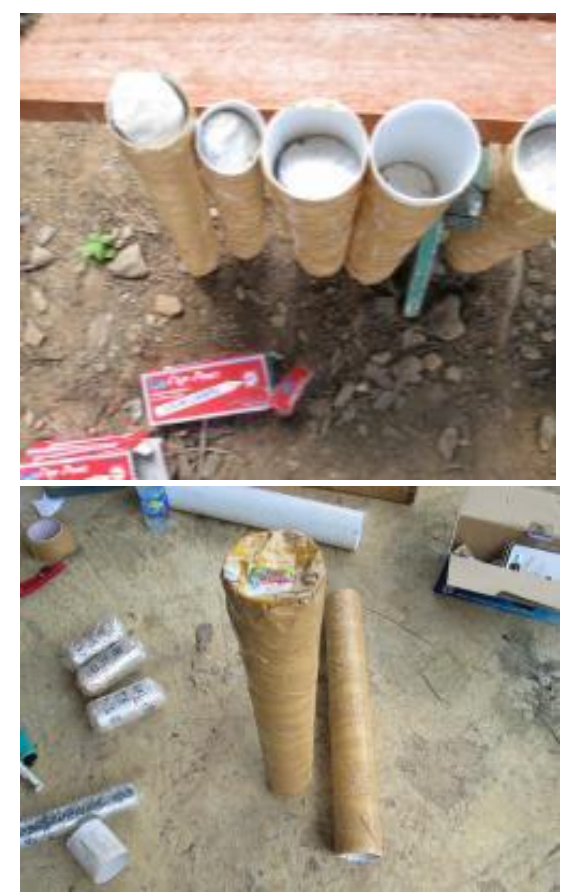

Gambar 3. Preparasi contoh batuan menggunakan PVC dan parafin.

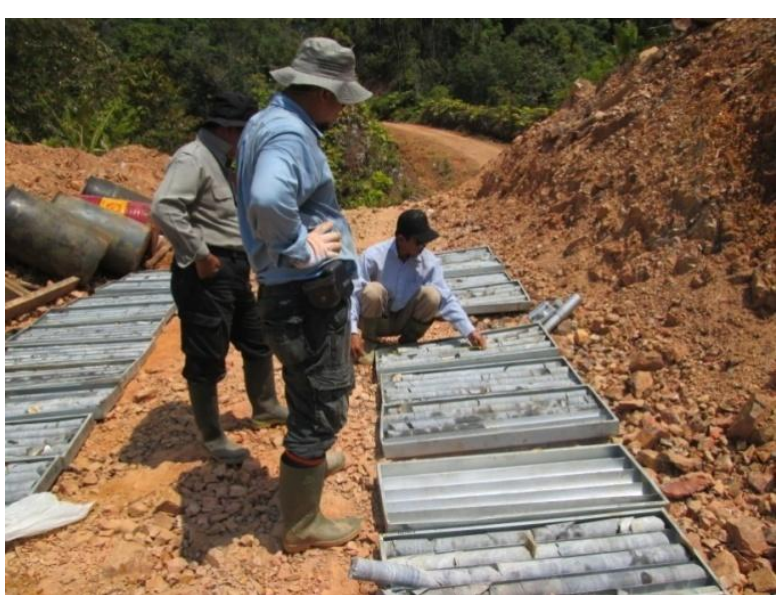

Gambar 4. Pekerjaan deskripsi inti bor. 
Tabel 4. Pengertian kelas massa batuan dari RMR (modifikasi Bieniawski) ${ }^{[9]}$.

\begin{tabular}{|c|c|c|c|c|c|}
\hline \multirow{2}{*}{$\begin{array}{l}\text { Parameter massa } \\
\text { batuan } \\
\text { Nilai }\end{array}$} & \multicolumn{5}{|c|}{ Rock Mass Class (Kelas Massa Batuan) } \\
\hline & $\begin{array}{l}\text { 100-81, } \\
\text { Kelas I }\end{array}$ & $\begin{array}{l}80-61, \\
\text { Kelas II }\end{array}$ & $\begin{array}{l}60-41, \\
\text { Kelas III }\end{array}$ & $\begin{array}{l}\text { 40-21, } \\
\text { Kelas IV }\end{array}$ & $\begin{array}{l}<20, \\
\text { Kelas V }\end{array}$ \\
\hline $\begin{array}{l}\text { Klasifikasi massa } \\
\text { batuan }\end{array}$ & Sangat baik & Baik & Cukup & Buruk & Sangat Buruk \\
\hline $\begin{array}{l}\text { Rata-rata waktu } \\
\text { stand-up }\end{array}$ & $\begin{array}{l}10 \text { tahun untuk } \\
\text { rentang } 15 \mathrm{~m}\end{array}$ & $\begin{array}{l}6 \text { bulan untuk } \\
\text { rentang } 8 \mathrm{~m}\end{array}$ & $\begin{array}{l}1 \text { minggu untuk } \\
\text { rentang } 5 \mathrm{~m}\end{array}$ & $\begin{array}{l}10 \text { jam untuk } \\
\text { rentang } 2.5 \mathrm{~m}\end{array}$ & $\begin{array}{l}30 \text { menit untuk } \\
\text { rentang } 1 \mathrm{~m}\end{array}$ \\
\hline $\begin{array}{l}\text { Kohesi massa } \\
\text { batuan }\end{array}$ & $>400 \mathrm{kPa}$ & $300-400 \mathrm{kPa}$ & $200-300 \mathrm{kPa}$ & $100-200 \mathrm{kPa}$ & $<100 \mathrm{kPa}$ \\
\hline $\begin{array}{l}\text { Sudut friksi dari } \\
\text { massa batuan }\end{array}$ & $>15^{\circ}$ & $35^{\circ}-45^{\circ}$ & $25^{\circ}-35^{\circ}$ & $15^{\circ}-25^{\circ}$ & $<15^{\circ}$ \\
\hline
\end{tabular}

\section{HASIL DAN PEMBAHASAN}

Litologi sektor Lemajung terdiri atas metapelit biotit, metapelit sekistosan, metalanau, dan metapelit andalusit. Sesarsesar yang berkembang adalah sesar sinistral barat daya selatan - timur laut utara, sesar dekstral barat- timur yang di beberapa tempat berkembang menjadi sesar normal dan sesar sinistral barat laut utara - tenggara selatan ${ }^{[10]}$. Pada saat pekerjaan pemboran, dilakukan deskripsi inti bor yang ditujukan untuk mengamati jenis batuan, bidang mineralisasi, dan bidang struktur. Selain untuk kepentingan deskripsi mineralisasi, perhitungan RQD, spasi rekahan, dan pengamatan permukaan bidang rekahan juga dilakukan untuk aplikasi geologi teknik (Gambar 5).

Nilai kuat tekan uniaksial dari batuan utuh (intact rock) di Sektor Lemajung diperoleh dari hasil uji UCS di laboratorium. Contoh batuan diambil dari inti bor dengan panjang lebih dari $30 \mathrm{~cm}$ dan berukuran NQ. Pengambilan contoh diambil dari batuan yang ideal, tidak patah, dan mewakili suatu kisaran kedalaman batuan. Contoh batuan untuk UCS sesuai dengan ruang lingkup eksplorasi dan estimasi sumberdaya uranium, diambil dari batuan favorabel untuk keberadaan uranium yaitu metalanau pada lubang bor LEML-39 dan LEML-40 (Gambar 6).

Analisis laboratorium mekanika batuan menunjukkan hasil nilai natural density berkisar antara $2.627-2.705 \mathrm{gr} / \mathrm{cm}^{3}$, saturated density antara $2.661-2.716 \mathrm{gr} / \mathrm{cm}^{3}$, dry density antara 2.620-2.700 gr/ $\mathrm{cm}^{3}$, specific gravity antara 2.72-2.74, natural water content antara 0.16-0.44 \%, degree of saturation antara 16.70-53.83 \%, porosity antara 1.55-4.09\%, void ratio antara 0.02-0.04, uniaxial compressive strength antara 390.94-1383.27 $\mathrm{kg} / \mathrm{cm}^{2}$, modulus of elasticity antara 26.9-36.6 $\mathrm{GPa}$, dan poisson's ratio antara $0.40-0.43$ (Tabel 5). 


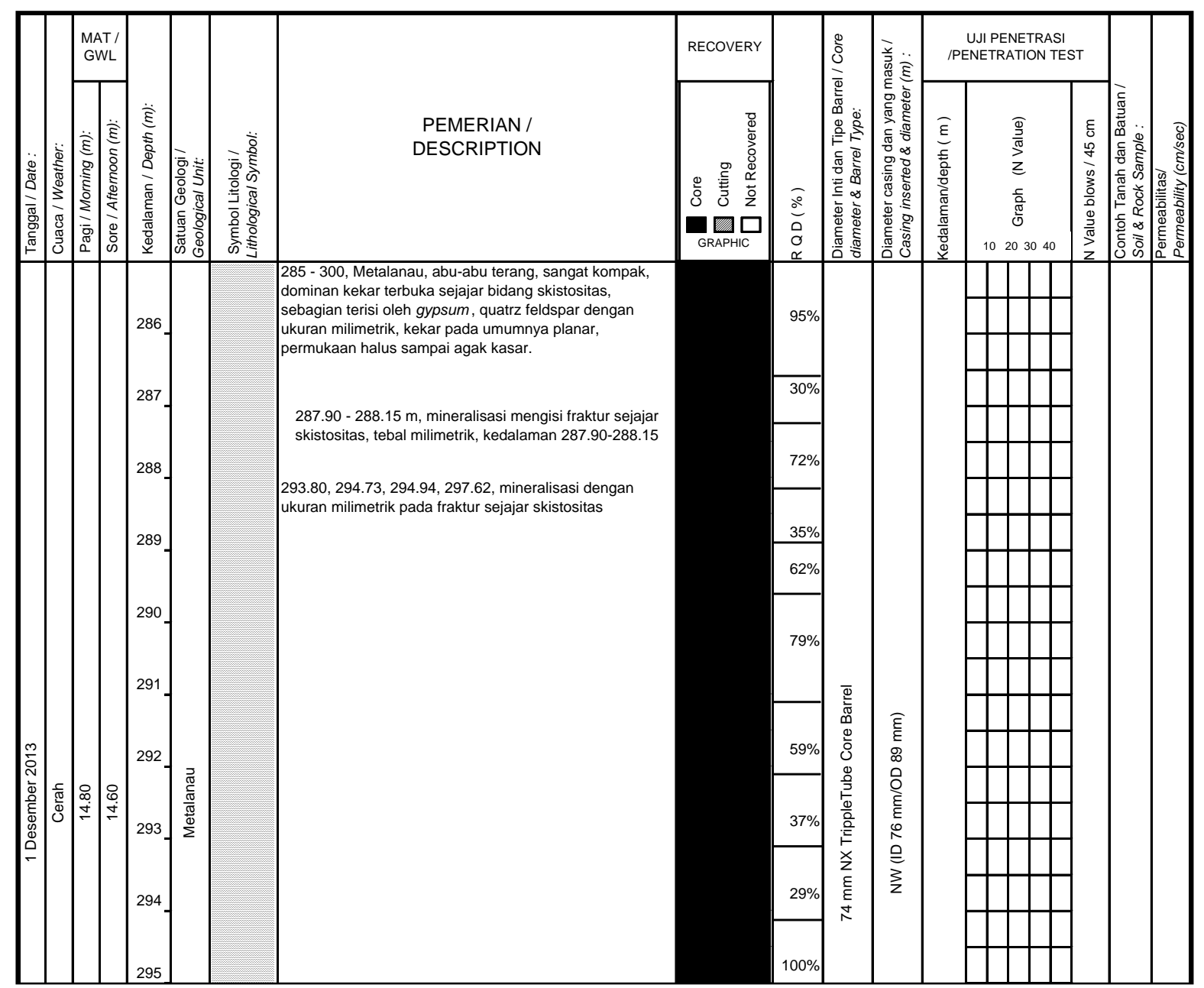

Gambar 5. Contoh deskripsi batuan pada LEML-42 kedalaman 285-295 m.

Hasil pengujian dari laboratorium selanjutnya dibandingkan dengan parameter pada sifat utama dalam klasifikasi tanah dan batuan (Tabel 1). Berdasarkan hasil perbandingan hasil pengujian laboratorium diketahui bahwa nilai kuat tekan uniaksial berada pada nilai 38 sampai dengan 136 atau kuat tekan rendah sampai tinggi. Terdapat gradasi perubahan nilai kuat tekan uniaksial dari kedalaman rendah sampai kedalaman tinggi, yaitu diantara kekuatan rendah pada kedalaman sekitar $60 \mathrm{~m}$ menjadi kekuatan menengah pada kedalaman sekitar 130 sampai $200 \mathrm{~m}$ dan menjadi kekuatan tinggi pada sekitar 260 sampai $280 \mathrm{~m}$. Rasio modulus batuan yang merupakan perbandingan antara modulus elastisitas dan kuat tekan uniaksial menunjukkan batuan Lemajung berada pada nilai 10 sampai 39 atau rasio modulus rendah (Tabel 6).

Pengamatan dan perhitungan RQD dimulai dari batas perlapisan antara tanah dan batuan. Pada titik bor LEML-38 kedalaman batuan berada pada $20 \mathrm{~m}$, nilai RQD berkisar antara 20-100\%. Pada titik bor LEML-39 batuan berada pada kedalaman $6 \mathrm{~m}$, nilai RQD berkisar antara 0-100\%. Pada titik bor LEML-40 batuan berada pada kedalaman 15 $\mathrm{m}$, nilai RQD berkisar antara 0-100\%. Pada titik bor LEML-41 batuan berada pada kedalaman 5,8 m dan nilai RQD 13,5-98,8\%. Pada titik bor LEML-42 batuan berada pada kedalaman $14 \mathrm{~m}$, nilai RQD berkisar antara 0$100 \%$ (Gambar 7). 


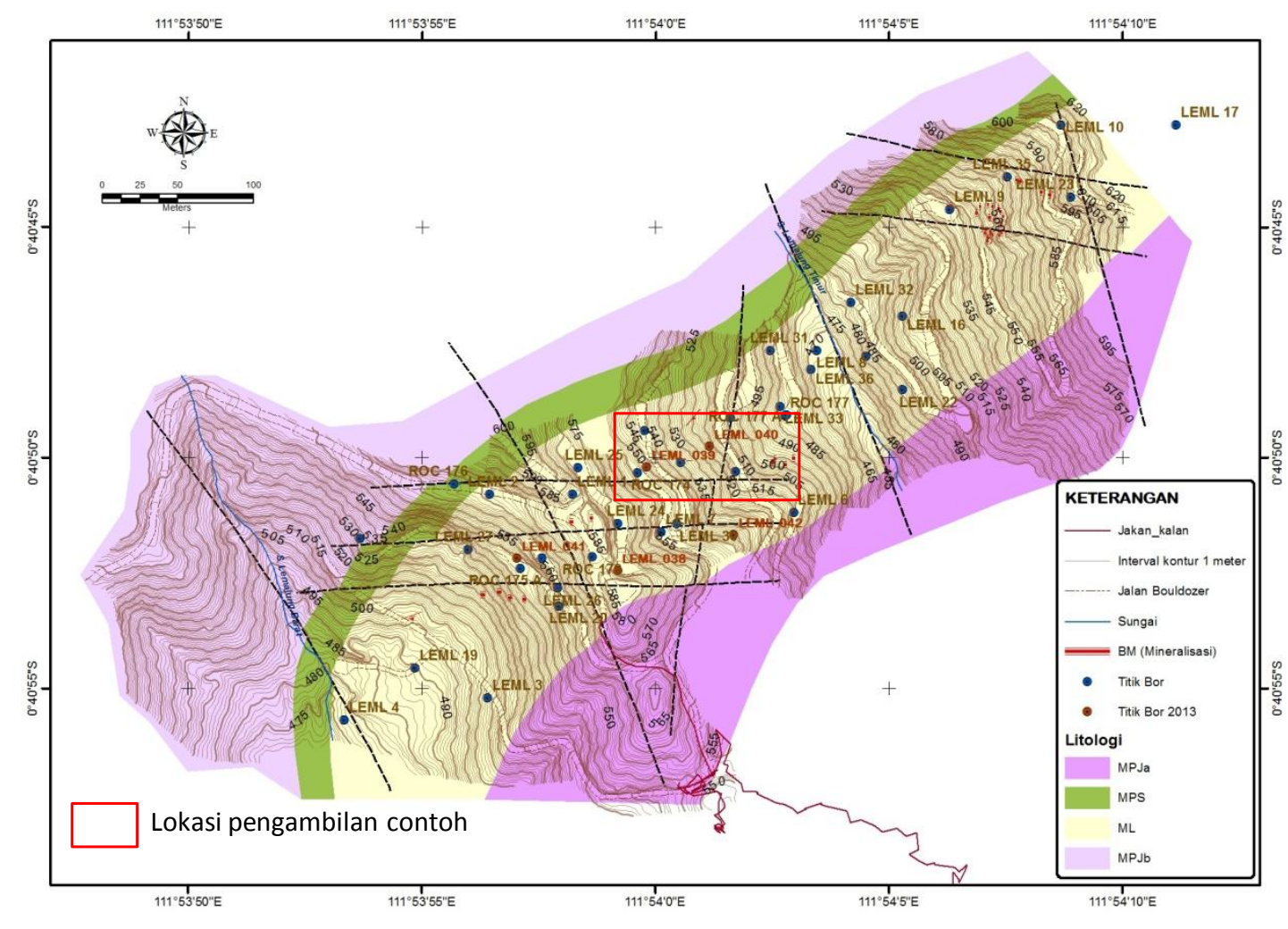

Gambar 6. Peta lokasi pengambilan contoh ${ }^{[1]}$.

Tabel 5. Hasil uji sifat fisik dan mekanik dari Puslitbang Tekmira

\begin{tabular}{|c|c|c|c|c|c|c|}
\hline \multirow{2}{*}{$\frac{\text { Bore Hole }}{\text { Sample Code }}$} & & \multicolumn{2}{|c|}{ LEML-39 } & \multicolumn{3}{|c|}{ LEML-40 } \\
\hline & & GT-7 & GT-8 & GT-9 & GT-10 & GT-11 \\
\hline Depth $(m)$ & & $\begin{array}{l}198.00- \\
198.40\end{array}$ & $\begin{array}{c}264.75- \\
265.00\end{array}$ & $\begin{array}{l}64.85- \\
65.20\end{array}$ & $\begin{array}{c}132.40- \\
132.75\end{array}$ & $\begin{array}{l}283.10- \\
283.50\end{array}$ \\
\hline \multicolumn{7}{|l|}{ Physical characteristic } \\
\hline - Natural Density & $\left(\mathrm{gr} / \mathrm{cm}^{3}\right)$ & 2.674 & 2.648 & 2.627 & 2.677 & 2.705 \\
\hline - Saturated Density & $\left(\mathrm{gr} / \mathrm{cm}^{3}\right)$ & 2.685 & 2.678 & 2.661 & 2.696 & 2.716 \\
\hline - Dry Density & $\left(\mathrm{gr} / \mathrm{cm}^{3}\right)$ & 2.662 & 2.640 & 2.620 & 2.670 & 2.700 \\
\hline - App.S.G & & 2.66 & 2.64 & 2.62 & 2.67 & 2.70 \\
\hline - True $S . G$ & & 2.72 & 2.74 & 2.73 & 2.74 & 2.74 \\
\hline - Natural Water Content & $(\%)$ & 0.44 & 0.29 & 0.26 & 0.26 & 0.16 \\
\hline - Kadar Air Jenuh (Absortion) & $(\%)$ & 0.84 & 1.43 & 1.56 & 0.96 & 0.57 \\
\hline - Degree of Saturation & $(\%)$ & 53.83 & 20.37 & 16.70 & 24.65 & 30.81 \\
\hline - Porosity & $(\%)$ & 2.23 & 3.78 & 4.09 & 2.56 & 1.55 \\
\hline - Void Ratio & & 0.02 & 0.04 & 0.04 & 0.03 & 0.02 \\
\hline \multicolumn{7}{|l|}{ Mechanic characteristic } \\
\hline \multirow[t]{3}{*}{ - Unconfined Comp. Strength } & $\sigma c\left(\mathrm{~kg} / \mathrm{cm}^{2}\right)$ & 789.09 & 1257.52 & 390.94 & 641.34 & 1383.27 \\
\hline & $E\left(\mathrm{~kg} / \mathrm{cm}^{2}\right)$ & 273884 & 372804 & 310287 & 232054 & 282654 \\
\hline & $v$ & 0.40 & 0.43 & 0.42 & 0.43 & 0.41 \\
\hline
\end{tabular}


Tabel 6. Sifat utama dalam klasifikasi tanah dan batuan di Sektor Lemajung

\begin{tabular}{|c|c|c|c|c|c|}
\hline Contoh & $\begin{array}{l}\text { Kedalaman } \\
(\mathbf{m})\end{array}$ & $\begin{array}{l}\text { Kuat tekan uniaksial / } \sigma c \\
\text { (MPa) }\end{array}$ & $\begin{array}{c}\mathbf{E} \\
(\mathbf{M P a})\end{array}$ & Rasio & Modulus \\
\hline LEML-40 GT-9 & $64,8-65,2$ & 38 (Kekuatan rendah) & 30430 & 39 & (Rendah) \\
\hline LEML-40 GT-10 & $132,4-132,75$ & (Kekuatan menengah) & 22758 & 18 & (Rendah) \\
\hline LEML-39 GT-7 & $198-198,4$ & (Kekuatan menengah) & 26860 & 17 & (Rendah) \\
\hline LEML-39 GT-8 & $264,75-265$ & (Kekuatan tinggi) & 36561 & 15 & (Rendah) \\
\hline LEML-40 GT-11 & $283,1-283,5$ & (Kekuatan tinggi) & 27720 & 10 & (Rendah) \\
\hline
\end{tabular}
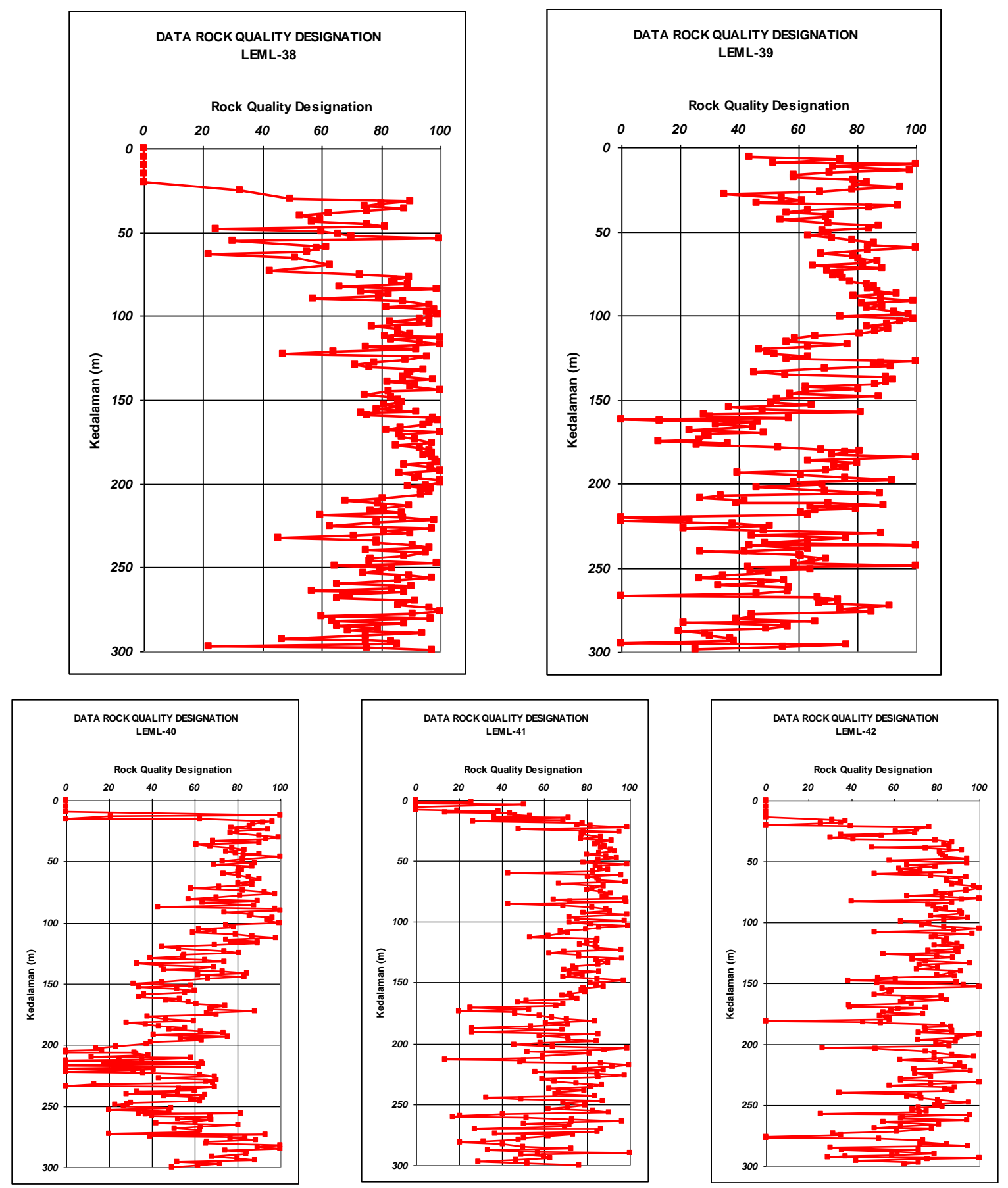

Gambar 7. Data RQD pada lubang bor LEML-38 sampai LEML-42. 
Pengamatan spasi rekahan dilakukan dengan pengukuran jarak antara rekahan yang dapat diamati pada inti bor (Gambar 8). Beberapa rekahan yang diakibatkan oleh proses pemboran seringkali teramati. Namun, pada beberapa rekahan dapat dibedakan dengan permukaan yang tidak lurus atau terpatahkan. Beberapa pasangan rekahan dapat diamati dan diukur. Untuk mendapatkan nilai rata-rata dari pasangan rekahan tersebut menggunakan metode Palmstrom ${ }^{[7]}$, dengan rumus:

$$
\frac{1}{S a}=\frac{1}{S 1}+\frac{1}{S 2}+\frac{1}{S 3}+\frac{1}{d s t} .
$$

Keterangan:

$S a=$ jarak rata-rata rekahan,

$S 1 / S 2 / S 3 / d s t=$ jarak antara pasangan rekahan.

Perhitungan spasi rekahan dilakukan berdasarkan core run dimana contoh batuan diambil untuk analisis laboratorium UCS
(Gambar 8). Hasil perhitungan spasi rekahan menghasilkan nilai antara 4 sampai $145 \mathrm{~cm}$.

Inti bor tidak dapat dijadikan dasar untuk menentukan parameter kontinuitas seperti pada pengamatan singkapan batuan. Namun, beberapa parameter lainnya seperti kekasaran, separasi rekahan, dan pelapukan dapat ditentukan. Rekahan di lokasi penelitian terbentuk pada bidang S0 yang merupakan bidang perlapisan batuan dan bidang $\mathrm{S} 1$ yang merupakan bidang foliasi. Bidang S1 pada umumnya mempunyai ketebalan pengisian bervariasi antara $1 \mathrm{~cm}$ sampai lebih dari $3 \mathrm{~m}$. Selain itu, bidang rekahan terisi oleh gipsum dengan ketebalan sentimetrik yang merupakan fase terakhir struktur. Kondisi bidang rekahan secara dominan teramati agak kasar dengan renggangan lebih kecil dari 1 mm dan tidak lapuk (Gambar 9).

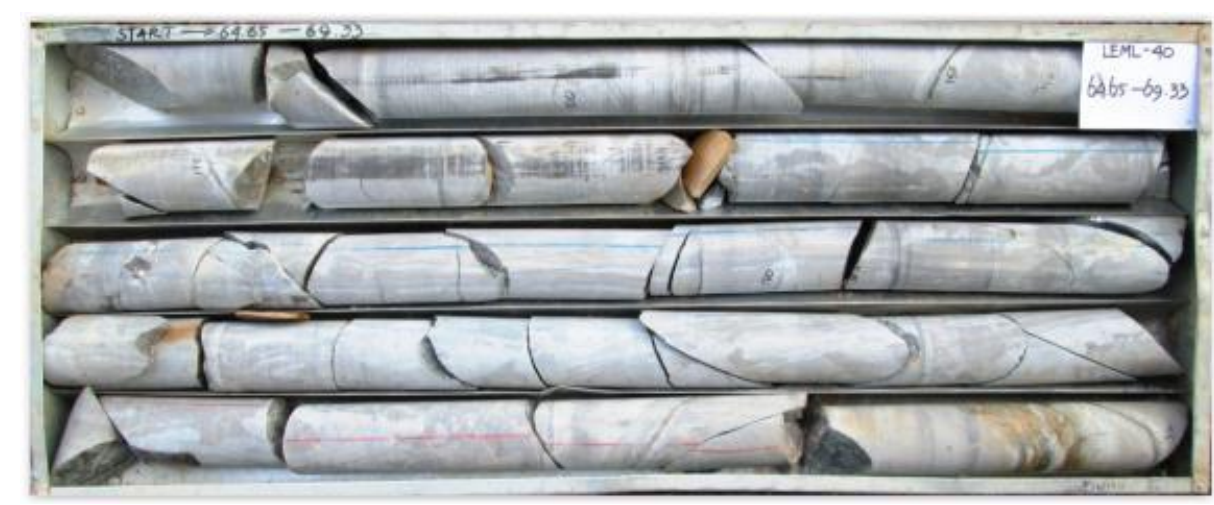

Gambar 8. Foto inti bor pada LEML-40 kedalaman 64,65 - 69,33 m. 


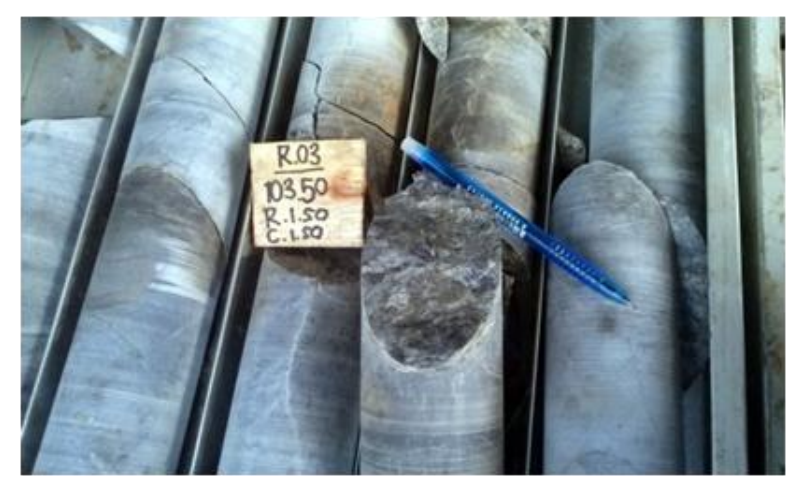

Gambar 9. Kondisi permukaan bidang rekahan pada bor LEML-38 (R03).

Kondisi airtanah di Lemajung berdasarkan pengamatan muka airtanah berada pada kedalaman sekitar 10-15 m. Berdasarkan pengamatan litologi yang keras dan kekar yang tertutup maka diasumsikan permeabilitas batuan sangat kecil. Kondisi tersebut dapat juga diamati dari bukaan terowongan eksplorasi di Eko-Remaja. Pada umumnya aliran airtanah lebih kecil dari 10 liter/menit setiap panjang $10 \mathrm{~m}$.

Berdasarkan hasil analisis parameter kekuatan contoh batuan, rock quality designation (RQD), jarak rekahan, kondisi rekahan, dan airtanah maka disimpulkan batuan metalanau mempunyai nilai $\mathrm{RMR}_{\text {basic }}$ antara 56 atau fair rock sampai 82 atau very good rock (Tabel 7). Untuk kepentingan desain bukaan bawah tanah seperti diuraikan oleh Bieniawski (1978), nilai RMR tersebut dapat diartikan waktu stand-up rata-rata pada bukaan antara 1 minggu untuk rentang $5 \mathrm{~m}$ sampai 10 tahun untuk rentang $15 \mathrm{~m}$, kohesi massa batuan 200 sampai $>400 \mathrm{kPa}$, dan sudut friksi massa batuan $25->45^{\circ}$.

\section{KESIMPULAN}

Karakterisasi massa batuan diperlukan dalam suatu rancangan terowongan pada tambang bawah tanah dimana perhitungan sifat-sifat teknis dari massa batuan menjadi hal yang penting untuk diperhatikan. Hasil analisis menyimpulkan bahwa metalanau sebagai litologi yang mengandung uranium di Sektor Lemajung mempunyai nilai rock mass rating (RMR) sebesar 56 atau kelas massa batuan III: fair rock pada kedalaman sekitar 60 m, dan pada kedalaman 280 m nilai RMR mencapai 82 atau kelas massa batuan I: very good rock. Data nilai RMR tersebut selanjutnya dapat digunakan dalam analisis pembuatan terowongan pada tambang bawah tanah atau analisis kestabilan lereng pada model tambang terbuka. 


\begin{tabular}{|c|c|c|c|c|c|c|}
\hline & 可 & ㄴ & $\hat{6}$ & 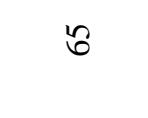 & $\tilde{6}$ & $\infty$ \\
\hline 馬 & 鞄 & & 음 & $ㅇ$ & 으 & 음 \\
\hline$\stackrel{1}{*}$ & 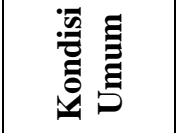 & $\begin{array}{l}\text { है } \\
\text { E్ } \\
\text { Q }\end{array}$ & 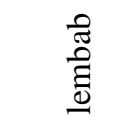 & 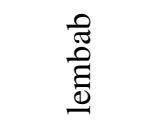 & $\begin{array}{l}\text { है } \\
\text { हี } \\
\text { ఏ }\end{array}$ & $\begin{array}{l}\text { है } \\
\text { है } \\
\text { E }\end{array}$ \\
\hline 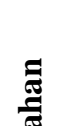 & 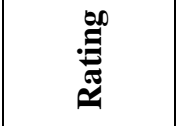 & ㄱ. & $\approx$ & $\ddot{\imath}$ & $\ddot{n}$ & $\curvearrowleft$ \\
\hline 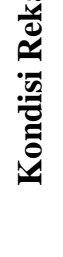 & 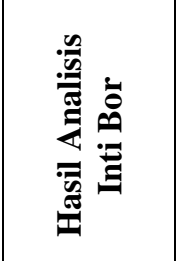 & 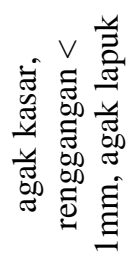 & 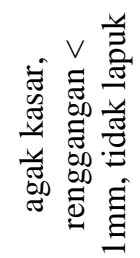 & 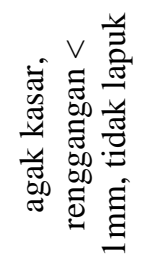 & 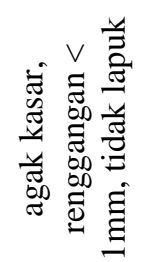 & 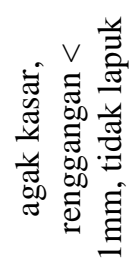 \\
\hline 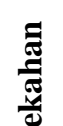 & 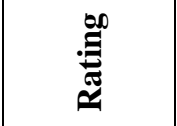 & $n$ & $\infty$ & & $\infty$ & 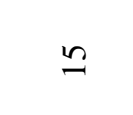 \\
\hline 䨠 & 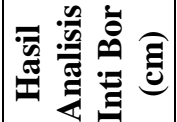 & $\nabla$ & $\simeq$ & $\bar{m}$ & $\underline{0}$ & $\stackrel{n}{ \pm}$ \\
\hline & & $\beth$ & $\underline{m}$ & $\underline{m}$ & $\infty$ & ิㅗ \\
\hline$\approx$ & 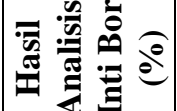 & 8 & $\stackrel{2}{2}$ & $\stackrel{\infty}{n}$ & fo & 8 \\
\hline 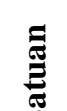 & & $\nabla$ & $r$ & $r$ & $\simeq$ & $\simeq$ \\
\hline 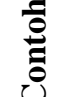 & 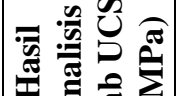 & $\stackrel{\infty}{m}$ & $\tilde{6}$ & 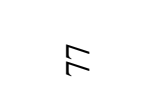 & 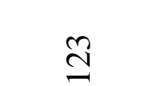 & $\stackrel{0}{2}$ \\
\hline 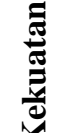 & 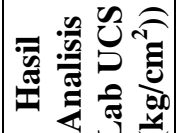 & बे & $\vec{J}$ & $\stackrel{\infty}{\infty}$ & 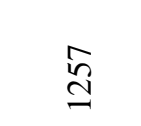 & $\begin{array}{l}m \\
\stackrel{\infty}{\sim}\end{array}$ \\
\hline & 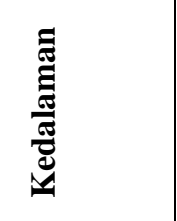 & $\begin{array}{l}\text { ते } \\
\hat{b} \\
0 \\
0 \\
0 \\
\dot{b}\end{array}$ & 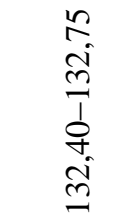 & $\begin{array}{l}9 \\
\infty \\
\infty \\
0 \\
8 \\
\infty \\
\infty \\
0\end{array}$ & $\begin{array}{l}8 \\
0 \\
i \\
i \\
n \\
i \\
i d \\
\text { i }\end{array}$ & 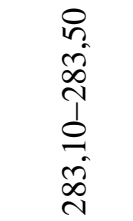 \\
\hline & 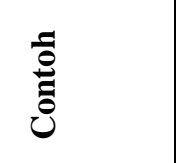 & $\underset{\sum_{I=1}^{+}}{\stackrel{P}{1}}$ & 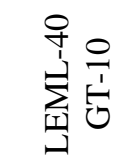 & 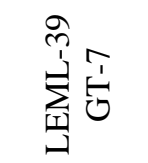 & 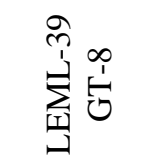 & 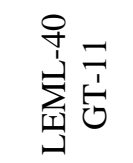 \\
\hline
\end{tabular}




\section{DAFTAR PUSTAKA}

1. SYAEFUL, H., SUHARJI, dan SUMARYANTO, A., "Pemodelan Geologi dan Estimasi Sumberdaya Uranium di Sektor Lemajung, Kalan, Kalimantan Barat", Prosiding Seminar Nasional Teknologi Energi Nuklir, Pontianak, 2014.

2. SEN, Z., and SADAQAH, B.H., "Modified Rock Mass Classification System by Continuous Rating", Engineering Geology, 67, 269-280, Elsevier Science, , 2003.

3. BIENIAWSKI, Z.T., "Engineering Rock Mass Classification", Wiley, New York, 1989.

4. FERRARI, F., APUANI, T., and GIANI, G.P., "Rock Mass Rating Spatial Estimation by Geostatistical Analysis", International Journal of Rock Mechanics and Mining Science, 70, 162-176, 2014.

5. EDELBRO, C., "Rock Mass Strength - a Review", Technical Report, Lulea University of Technology, Lulea, 2003.

6. BIENIAWSKI, Z.T., "Rock Mass Classification in Rock Engineering", In Exploration for Rock Engineering, Proceeding of the Symposium, 1, 97-106, Balkema, Cape Town, 1976.

7. PALMSTROM, A., "Measurement and Characterization of Rock Mass Jointing, In-situ Characterization of Rocks", Sharma V.M. and Saxena K.R., A.A. Balkema Publishers, 49-97, 2001.

8. DEERE, D.U., and DEERE, D.W., "Rock Quality Designation (RQD) after Twenty Years", US Army Corps of Engineer, Washington, 1989.

9. BIENIAWSKI, Z. T., "Determining Rock Mass Deformability", International
Journal of Rock Mechanics Mining Sciences, 15, 335-343, 1978.

10. NGADENIN, dan SULARTO, P., "Evaluasi Model Struktur Geologi dan Pola Mineralisasi Uranium Sektor Lemajung Barat, Cekungan Kalan, Kalimantan Barat", Prosiding Presentasi Ilmiah Daur Bahan Bakar Nuklir V PTBDU dan P2BGN - BATAN, Jakarta, 2000. 